\title{
Correction activities by France's supreme courts and control over their dockets
}

\author{
Pierre Bentata $^{\ddagger}$ Romain Espinosa** Yolande Hiriart ${ }^{\dagger \dagger}$
}

February 2018

\begin{abstract}
The aim of this paper is to observe how supreme courts use their discretionary power over their dockets to correct appellate courts' decisions relative to their own interpretation of the law. There are two supreme courts in France, the Conseil d'État for the administrative branch, and the Cour de Cassation for the civil one. In both courts, at different dates though, a reform took place that gave them discretionary control over their dockets. Hence, a difference in the supreme courts' decisions might be due to either different correction activities, selection strategies, or both. Accordingly, it is necessary to distinguish between them before drawing any conclusions about supreme courts' behaviors. We develop an econometric approach to assess whether the correction activities are similar between supreme courts, and whether these activities are affected when the supreme courts can select cases. Using an original database of all environmental cases determined by the supreme courts between 1956 and 2010, we rely on a counterfactual approach to compare cases across the courts before and after the reforms. Our study concludes that correction activities do not differ across the courts as long as they are submitted to the same selection rule. We also find that the supreme courts use the possibility of selection to increase their pro-plaintiff correction activities in a way that affects the overall probability of success of plaintiffs and defendants.
\end{abstract}

JEL classification: K32, K41

Keywords: litigation, judicial review, appeal process, selection bias, bias correction, French environmental cases, appellate court, supreme court, administrative law, civil law, judicial reform.

\footnotetext{
${ }^{*}$ We thank participants at the Mannheim Law and Economics Forum (MaLEF seminar), University of Mannheim (November, 2014), the 31st Annual Conference of the European Association of Law and Economics (EALE), Aix-enProvence, France (September, 2014), the First Annual Conference of the French Association of Environmental and Resource Economists (FAERE), Montpellier (September, 2014), the 64th annual Meeting of the French Economic Association (June, 2015), the 2nd International Meeting in Law and Economics, Nanterre (June, 2015), the First Conference in Empirical Legal Studies in Europe, Amsterdam (June, 2016), and the 3rd International Conference on Economic Analysis of Litigation, Montpellier (June, 2016). The research leading to these results has received funding from the Institut Universitaire de France (IUF).

${ }^{\ddagger}$ ESC Troyes. Email: pierre.bentata@get-mail.fr.

** CNRS, CREM - Université de Rennes 1. Email: romain.espinosa@univ-rennes1.fr.

${ }^{\dagger \dagger}$ Université de Franche-Comté (CRESE) and Institut Universitaire de France (IUF), France. E-mail: yolande.hiriart@univ-fcomte.fr.
} 


\section{Introduction}

One justification for the existence of supreme courts is the need to harmonize the way in which the judicial system applies the law. The disparity of legal decisions within a single legal framework can be perceived as a threat to equality before the law: litigants should expect to face the same application of the rules independently of the judge before whom they appear at trial. In this regard, the hierarchical structure of the judiciary, dominated by supreme courts, can be considered an appropriate solution: litigants can challenge the decisions of appellate courts. Supreme courts' judges use this appeal process to reverse (resp. uphold) appellate court decisions they consider inappropriate (resp. appropriate). Supreme courts therefore have the opportunity to correct decisions of appellate courts due to improper application of the law, to clarify unclear legal issues, and, sometimes, to limit judicial activism. Although non-legal factors may affect the decision-making of supreme courts, this final appeal to a single court greatly contributes to aligning case-law on a single interpretation of legal rules. The main role of the supreme courts is thus to align the appellate courts' application of legal rules on theirs, or, in other words, to correct the appellate courts' decisions to fit their own interpretation of legal rules.

Although supreme courts contribute to harmonizing the legal framework, they are not exempt from political and/or judicial bias. Several works have shown that justices of the supreme courts may indeed be motivated by non-legal factors such as ideological preferences or political pressure; they may also be influenced by peer biases. In this respect, supreme courts may take advantage of the opportunity to overrule appellate courts' decisions so as to align case law with their own preferences: supreme courts might correct appellate courts' biases relative to their own.

The aim of this paper is to observe how supreme courts use this discretionary power in the French context. In the French legal system, due to their different backgrounds, civil and administrative judges from lower courts may have different biases that may influence their decisions, especially their severity towards defendants (State, state representatives and state-own companies for administrative courts vs private companies and individuals for civil courts). Consequently, administrative and civil supreme courts' judges may choose different selection strategies according to their perceptions of those biases. Hence, observing their selection strategies could shed light on how judges from both supreme courts perceive the decisions and the biases of lower courts' judges from their own jurisdiction (administrative vs civil). In other words, different selection strategies in civil and administrative supreme courts would reveal that supreme courts' judges from one jurisdiction are more concerned with potentially biased decisions from lower courts' decisions than supreme courts' judges from the other jurisdiction. Moreover, this would reveal that the interpretation of legal rules by appellate judges and supreme court's judges differ more in one jurisdiction than in the other.

To explore the correction activities of the supreme courts, we evaluate 614 supreme civil and administrative courts' decisions in the field of environmental accidents from 1956 to 2010, and test for a difference in treatment between the two courts. We run Probit estimations to assess the 
impact of the supreme courts on defendants' win rates. Following Shavell (1995), we assume that the supreme courts can engage in correction activities with respect to appellate courts' errors and biases, especially if the former have a discretionary control over their dockets and can focus on potentially biased decisions from appellate courts (Eisenberg et al. (2012)). Hence, the greater the discrepancy between the appellate courts' and the supreme courts' preferences, the more the latter are expected to engage in correction activities and, therefore, to reverse the appellate courts' decisions.

Previous studies of supreme courts' decisions have emphasized the importance of considering case selection (Kastellec and Lax (2008)). ${ }^{1}$ Indeed, the case selection process, whereby supreme courts can choose the cases they hear, leads to biased observed samples. As case selection strategies are not usually publicized, any inference from case outcomes is potentially flawed. In our study, selection bias is a major issue as the two supreme courts have both been allowed to select their cases, though at different dates. It is therefore very likely that the correction activities of the supreme courts (vis-à-vis appellate courts) may be affected by the selection mechanisms: supreme courts that hold very different beliefs from their appellate courts may use selection mechanisms to focus more intensively on reversal decisions. Indeed, a difference between the two supreme courts' decisions might be due to different correction activities vis-à-vis appellate courts or to different case selection strategies, or both. Consequently, it is necessary to distinguish the impact of each "bias" (correction and selection) before drawing any conclusion.

Our investigation consists in two steps. First, we compare the correction behavior of both supreme courts. This first part seeks to figure out whether the Conseil d'État (supreme administrative tribunal) engages in more correction activities of the appellate courts' decisions than the Cour de Cassation (supreme civil court). This allows us to indirectly assess the relative distance in the courts' preferences between the appellate and their respective supreme levels. Second, we go a step further by quantifying how case selection affects the correction activity of the highest instances: we investigate whether the supreme courts, when they are allowed to select cases, change their correction activities vis-à-vis the appellate courts' decisions.

The paper shows that, over the entire period, the Conseil d'État engages in more correction activities than the Cour de Cassation. However, decomposing the whole period according to the selection capacity of each court, we find that the supreme courts' correction activities are similar in their intensity when both courts share the same selection mechanism.In other words, observed differences in correction activities are only due to the fact that one supreme court could select its dockets before the other but not to the fact that one supreme court tend to engage in more correction that the other.

\footnotetext{
${ }^{1}$ Selection biases have different sources which can go back to the origins of a case. It is generally admitted that the set of trials which take place in a lower court is not necessarily representative of the whole set of potential trials. Some case categories can be favored by the plaintiffs if they feel they have more chances of success. Even the set of plaintiffs (and thus of parties) may not be fully representative of the set of potential plaintiffs (and parties): the decision to sue can depend on the nature of the plaintiff (an individual, a firm), the level of education, the knowledge of the legal system and the level of wealth. Biases can be created at the origin of a trial, and propagate throughout the appeal processes up to the supreme courts' level: in theory, some biases can be created at each stage due to factors affecting the decision of appellants to file the case.
} 
The rest of the paper is organized in the following way. Section 2 reviews the relevant literature. Section 3 depicts the legal background whereas Section 4 describes the data and presents some statistics and preliminary econometric results. Section 5 develops our econometric strategy to assess the correction activities of each supreme court over time. Section 6 concludes.

\section{Prior literature}

Two strands of literature relate to our paper. A first body of works has investigated whether judges' characteristics and their environment impact their decisions. We refer to this literature as the study of judges' biases. A second set of papers is dedicated to the methodology and the biases relative to the empirical study of case outcomes and courts' decisions. We refer to this literature as the study of selection biases.

Over the last decades, judges' biases have been abundantly studied. Indeed, some authors have investigated the effects of gender (Choi et al. (2011), Greiner and Rubin (2011), Bogoch and DonYechiya (1999)), religion (Bornstein and K. (2009), Gazal-Ayal and Sulitzeanu-Kenan (2010)), race (Shayo and Zussman (2011)), or judges' political preferences (Choi and Gulati (2008), LambertMogiliansky et al. (2006), Ashenfelter et al. (1995), Hall (2010), Amaral-Garcia et al. (2009), Franck (2009), Martin et al. (2005), Spiller and Gely (1992), Espinosa (2015, 2017), Desrieux and Espinosa (2015)) on case outcomes. Others have studied the impact of the socio-economic environment on judges' decisions. For instance, Berger and Neugart (2011) report a positive link between the legal activity of German labour courts and unemployment. Ichino et al. (2003) observe that Italian labor courts are more favorable to employees when unemployment is high, a phenomenon also reported by Malo et al. (2016) from Spanish labor courts, whereas Marinescu $(2003,2011)$ concludes the opposite effect for the French and British labor courts respectively.

A second comprehensive stream of research has dealt with unequal treatment resulting from the composition of the courts or from the identity of the parties themselves. Clermont and Eisenberg (1992) show that plaintiffs' success rates differ significantly before judges and juries, since attorneys select more difficult cases when pleading before juries. Two other papers, Clermont and Eisenberg (2001), Clermont and Eisenberg (2002) show that defendants succeed more than plaintiffs on appeal from civil trials, explaining this phenomenon by appellate judges' attitudes. This difference has also been reported by Eisenberg (2004) and Eisenberg and Heise (2009). However, the fact that plaintiffs tend to appeal cases even when their chances of success are very slight might also explain the apparent pro-defendant bias (Eisenberg and Farber (2003), Eisenberg and Farber (2013)). Eisenberg et al. (2011) confirm this last point by showing that there are no asymmetric reversal rates favoring defendants in Israel's supreme court's appellate cases. In the closest paper to ours, Amaral-Garcia and Garoupa (2012) test for a pro-government bias in administrative tribunals in the field of medical malpractice in Spain. Studying the supreme court's decisions to compare civil and administrative appellate courts' adjudications, they conclude that there is no evidence of such a pro-government bias in administrative tribunals. 
Notwithstanding the progresses accomplished in the quantitative analysis of courts' decisions and judges' preferences, most of the authors fail to take into account biases that result from case selection. ${ }^{2}$ Indeed, investigations of courts' decisions might be flawed by several biases. First, a great proportion of cases are settled: consequently, inferences about courts' decisions might under- or overestimate the impact of the exogenous variables if they also affect the settlement decision (Priest and Klein (1984), Eisenberg (1990)). In the same vein, decisions to appeal are not random and, therefore, case outcomes in appellate courts do not necessarily reveal the actual severity -and potential biases- of lower courts' judges. In other words, selection biases limit the possibility of inferring general conclusions about judges' decisions and preferences from studies of case outcomes, especially if the focus is exclusively on the identity of the winning party (Clermont and Eisenberg (1998)). Another substantial selection bias arises when only a fraction of the whole caseload is published (Donohue and Siegelman (1990), Merritt and Brudney (2001), Law (2005)) as the choice to publish a decision may not be random.

Finally, the study of supreme courts' decisions is even more sensitive to selection biases: supreme courts focus on the most complex cases (Kritzer and Richards (2002)), which are not representative of the whole set of cases adjudicated by appellate courts (Cross (1997), Friedman (2006)). The reason for such selection biases is twofold. First, as for appellate courts, appeals to supreme courts are costly and not random. Second, most supreme courts have some discretionary control over their dockets and, therefore, can select the cases they review without having to explain their selection strategy. ${ }^{3}$ Hence, it is fundamental to cope with discretionary case selection before inferring general conclusions about supreme courts' preferences and potential biases (Harvey and Friedman (2009), Eisenberg et al. (2012), Eisenberg et al. (2014)) from the study of their case outcomes, as supreme courts' selection biases may substantially impact observed statistical results (Kastellec and Lax (2008)).

Although a growing number of scholars recognize the importance of case selection and develop different statistical methods to control for it, ${ }^{4}$ the impact of selection bias on correction activities has almost never been assessed. More importantly, no study, to our knowledge, analyzes how correction activities are affected by case selection rules. This is the gap we aim to fill.

\footnotetext{
${ }^{2}$ For instance, concerning the analysis of labor courts, Macis (2001) and Marinescu (2003) ignore out-of-court settlements and work with a sample biased by case selection since the choice to settle is not random. In the same vein, in their study of judges' ideology and its impact on case outcomes, Sunstein et al. (2006) only focus on published decisions. However, Keele et al. (2009) show that the choice to publish a decision is not random and therefore samples restricted to published cases are biased. Finally, some authors do not even mention the existence of sample and selection biases (e.g. Epstein and Martin (2010), Amaral-Garcia and Garoupa (2012)).

${ }^{3}$ See for instance Eisenberg et al. (2011), Eisenberg et al. (2012), Eisenberg et al. (2014), and Eisenberg and Huang (2012).

${ }^{4}$ For instance, Eisenberg and Huang (2012) use a reform of Taiwan's supreme court allowing for discretionary selection of cases as a quasi-natural experiment to observe judges' selection strategies. Eisenberg et al. (2014) compare discretionary and mandatory jurisdictions in Israel's supreme court to assess case selection. Hall (2010) uses random judicial assignment to control for selection biases when assessing the effect of appellate judges' partisanship on their decisions. Eisenberg et al. (2012) use key covariates to account for non-random aspects of case assignment. Finally, in a recent paper, Boyd et al. (2010) use a more sophisticated method based on propensity score matching to deal with non-random assignment of cases among male and female judges.
} 


\section{The French legal background: A quasi experiment for identifying selection biases}

\subsection{The French legislation: Two separate jurisdictions}

In France, as in many civil law countries, cases involving the state as litigant are dealt with by separate courts. Indeed, disputes between private parties only are dealt with by civil jurisdictions, whereas cases involving the state are determined by administrative tribunals. More precisely, in environmental cases, a dispute will be tried in the administrative tribunals if the defendant is a public legal person, a state-owned company, or a private company entitled to provide public services and exercising administrative authority. ${ }^{5}$ Absent this administrative authority, a private company providing public services will be sued in the civil courts. ${ }^{6}$ Hence, environmental administrative litigation may concern either a controversy over a decision of a state official (e.g. authorization to start a potentially environmentally unfriendly activity, implementation of a controversial local regulation, or stringency of an environmental impact assessment), or a dispute over an action of a public defendant that resulted in damages to private plaintiffs.

The main reason for such a distinction between private and public defendants is that "public authorities have specific powers and obligations that require that their action should not be reviewed by ordinary courts" (Frydman (2008)).

Consequently, liability is determined differently in administrative and civil courts. In Civil Law, fault-based liability is the rule (except for the most environmentally unfriendly facilities called ICPE facilities, ${ }^{7}$ which are subject to strict liability) and the criterion for negligence is the "reasonable man standard" (bon père de famille). In Administrative Law, the standard of care is much higher as state-owned companies and state officials have a duty to ensure health and safety, ${ }^{8}$ and cannot claim that their level of care was limited by a budget constraint. ${ }^{9}$ Furthermore, the procedures are also different. The procedure before administrative tribunals is inquisitorial (inquisitoire) whereas the civil procedure is accusatorial (accusatoire). This means that administrative tribunals direct the course of the procedure and are in charge of finding out the facts that may be relevant to their decisions (Frydman, 2008). ${ }^{10}$ Consequently, administrative judges have

\footnotetext{
${ }^{5}$ Private companies with a public service mission are subject to Administrative Law if they are entitled to take administrative decisions, i.e. they benefit from a "prérogative de puissance publique" (see Arrêt Magnier in CE 13 January 1961, and CE 15 May 1991, Association Girondins de Bordeaux FC).

${ }^{6}$ Tribunal des Conflits, 27 November 1995, Le Troedec, and Arrêt Temier in CE 6 February 1903.

${ }^{7}$ Installations classées pour la protection de l'environnement.

${ }^{8}$ The first reference to this obligation appeared in 1902 (Law of 15 February 1902, relative to the protection of public health). The criterion became more stringent over the century as many public health and environmental scandals occurred. For instance, the State was found responsible for "public health deficiencies" in the HIV-contaminated blood affair (CE 9 April 1992, n.138653) and in the asbestos affair (CE 3 March 2004, n.241153). For a detailed analysis of the evolution of the severity of the precautionary principle in French environmental law, see Bentata and Faure (2012).

${ }^{9}$ Cass. Crim., 2 July 1998, n.97-83.286.

${ }^{10}$ These differences between Administrative and Civil Law in the severity of the rules but also in the procedures renders the analysis quite uneasy, even with some control over a number of observable variables. For this reason, we do not give any definite conclusion in the end of Section 4, with the first regressions. Section 5 refines the analysis by
} 
more leeway than civil judges in taking their decisions.

\subsection{The appeal process: A common feature}

Despite their different rules, civil and administrative courts are organized along similar lines. Both are pyramidal with the Cour de Cassation and the Conseil d'État at the apex of the civil and the administrative branches, respectively. Civil and administrative cases are first tried in Cours d'Instance and in Cours Administratives d'Instance respectively, and can be appealed in Cours $d^{\prime}$ Appel and in Cours Administratives d'Appel. As far as litigation is concerned, ${ }^{11}$ the Cour de Cassation and the Conseil d'État share a common feature: both have to harmonize case law to ensure that texts are interpreted in the same way nationwide. ${ }^{12}$ Moreover, they do not rule on the merits of a case, but rather on the proper application of the rules by the appellate courts (i.e. both supreme courts rule on the decisions of the appellate courts). Hence, even though administrative and civil rules might differ, the task of judges from both supreme courts is similar. From this common role, it follows that it is meaningful to compare decisions of both supreme courts to the extent that cases are comparable. Controlling for the characteristics of the case, a difference in severity between the two supreme courts could indicate heterogeneous correction behaviors: supreme court judges may seek to correct some systematic mistakes of the appellate courts, though with different intensities.

\subsection{The potential for a pro-defendant bias in administrative tribunals}

In France, Administrative and Civil Law are considered quite separate branches of law, with their own logic and their own procedures. For this reason, administrative and civil judges often come from very different backgrounds. Civil judges (referred to as Magistrats) enjoy special statutory protection. To become civil judges, candidates have to attend the National School for the Judiciary (École Nationale de la Magistrature) for a period of 31 months. There are three different competitive examinations depending on the professional experience of the candidate: the first one is open to students with a Master degree in Law who are at least 27 years of age. The second and third ones are open to candidates who already have at least seven years' legal experience. Most civil judges come from the first examination process. ${ }^{13}$ As a result, the majority of successful candidates begin their professional careers as civil judges, and most of them remain civil judges until retirement.

The picture for the administrative branch is more complex. First of all, administrative judges are usually civil servants and not Magistrats. In this regard, they do not benefit from protections

providing some control over unobservable variables.

${ }^{11}$ Indeed, the Conseil d'État exercises two different roles: it is not only the supreme court of the administrative jurisdiction but also the most important legal advisor to the Government.

${ }^{12}$ See About the Court, Cour de Cassation, www.courdecassation.fr/about_the_court_9256.html.

${ }^{13}$ For instance, in 2006, $88 \%$ of newly graduated judges entered the National School for the Judiciary through the first examination process. See the statistics provided by the Cour de Cassation on its website: http:/ / www.courdecassation.fr/IMG/File/pdf_2007/10-05-2007/10-05-2007_mcKee_fr.pdf. 
that guarantee the independence of Magistrats from the State. Second, except for judges from the Conseil d'État who, for the majority, attended the National School of Administration (École Nationale d'Administration) after a highly competitive examination, administrative judges are recruited from among civil servants, lawyers, and high-flying law graduates. This phenomenon is explained by the relatively low number of students who intend to become administrative judges and the growing shortage of administrative judges in recent decades. As a matter of fact, over the last decade, only $19 \%$ of the new administrative judges had not been civil servants. ${ }^{14}$ This means that $81 \%$ of the new administrative judges used to work in close relationship with state officials and local authorities, i.e. precisely the parties they may have to judge once in charge. This situation is favorable to the emergence of sympathy towards a group (the group of public agents) to which administrative judges previously belonged. Such a context can potentially give rise to a pro-defendant bias. ${ }^{15}$

Unlike lower administrative tribunals, judges sitting in the Conseil d'État mainly come from a specialized school. Each year, five positions as auditors (Auditeurs) are made available to the top graduates of the National School of Administration. After four years, an auditor is promoted to master of petitions (Maître des requêtes) and, after twelve years, to the level of judge (Conseiller $d^{\prime}$ État). Promotion is based exclusively on seniority which ensures independence and impartiality in the promotion of members. Recruitment by external appointment accounts for one out of four masters of petitions and for one out of three judges. A number of external appointments, upon the nomination of the Vice-President of the Conseil d'État, is reserved for members of the administrative tribunals and the administrative appellate tribunals. ${ }^{16}$ Similarly to the lower administrative tribunals, one could question the impartiality of these judges towards the State. Judges who were appointed from the lower courts potentially suffer from the same pro-State biases. Moreover, judges from the National School of Administration might also be biased towards the State: their choice to devote their career to the public administration might reflect preferences favorable to the State.

\subsection{The potential for a selection bias in both supreme courts}

Like most of the supreme courts in other countries, the Cour de Cassation and Conseil d'État have some control over the cases filed that allow them to select the ones that will actually be heard. ${ }^{17}$ Considering this discretionary control, any econometric results about courts' decisions should be interpreted carefully. Indeed, judges' decisions can change as time passes, either because of external circumstances, or because selected cases have themselves changed. In the present study, the comparison of judgments by both courts can be distorted when they do not select similar cases. If both courts do not select cases in the same way, then a comparison of final

\footnotetext{
${ }^{14}$ See the statistics provided by the Cour de Cassation on its website: http:/ /www.courdecassation.fr/IMG/File/pdf_2007/10-05-2007/10-05-2007_recrutement_adm.pdf.

${ }^{15}$ Figure 2 in Appendix B provides a description of the French legal framework regarding the different courts

${ }^{16}$ See the website of the Conseil d'État: http:/ / english.conseil-etat.fr/.

${ }^{17}$ See Eisenberg et al. (2011). In France, $30 \%$ of the cases filed are declared "non-eligible" and rejected without publication of the underlying reasons in the legal databases.
} 
decisions will prevent us from determining whether one court is more severe than the other against defendants, or whether the initial selection was different. In other words, the possibility of selecting the cases to be reviewed increases the confusion between judges' preferences and selection bias.

For this reason, selection bias is often ignored or simply alluded to in empirical works analyzing supreme courts' decisions. However, the French situation is particularly interesting in this respect, since reforms of case eligibility criteria allow us to distinguish - at least partly - different biases. Indeed, the abolition of the filter designated as Chambre des Requetes in 1947 forced the Cour de Cassation to motivate its decisions whether or not to review the cases filed. This cumbersome process has increased the workload of the court causing further delays for judgment. For this reason, the organic law of 25 June $2001^{18}$ has restored the preliminary screening of files, allowing a case to be declared non-eligible without having to provide any detailed motivation for this rejection. ${ }^{19}$ This law came into force on 1 January 2002. ${ }^{20}$ Hence, for the period 1947 to 2001, the Cour de Cassation could not select the cases to be heard. ${ }^{21}$ The selection bias - at the Cour de Cassation's level - can only concern cases after 2001.22

A similar reform occurred for the Conseil d'État for which the preliminary screening of the cases was restored on 1 January 1989. ${ }^{23}$ Hence, cases judged before 1989 constitute a complete and unbiased sample of the cases adjudicated by the Conseil d'État. Only cases judged since 1989 can present the selection bias we identify.

\section{Database}

In order to investigate the correction behavior of the supreme courts together with the potential selection effects induced by the reforms, we study the entire set of decisions of the Cour de Cassation and the Conseil d'État concerning environmental accidents and damage between 1956 and 2010. Our database is compiled from two French official legal search engines that list all cases before the Cour de Cassation and the Conseil d'État since $1956 .{ }^{24}$ To collect the entire set of environmental cases, we used the keywords: pollution, trouble de voisinage (nuisance to neighborhood),

\footnotetext{
${ }^{18}$ Loi 2001-539 révisant l'Art. L 131-6 du Code de l'Organisation Judiciaire.

${ }^{19}$ See http://www.courdecassation.fr/cour_cassation_1/autres_publications_discours_2039/publications_2201/ admission_pourvois_cassation_8424.html.

${ }^{20}$ Art.28, Loi 2001-539.

${ }^{21}$ From a practical viewpoint, this means that legal databases collecting all the decisions taken in the Cour de Cassation do not present any selection bias - at the court's level - for this period. Appeals have been judged unacceptable or not motivated by serious reasons: in any event, the decision has been motivated by the court and codified in the databases.

${ }^{22}$ The selection bias that we manage to isolate in this paper is the one that occurs from the choice of cases to be heard by the supreme courts. This selection bias is potentially important, as explained earlier, but it is not the only possible one. Our approach allows us to isolate and quantify this selection bias, but not the ones that take place earlier in the history of a particular case, i.e. before the appeal at the supreme court's level.

${ }^{23}$ Art.16, Loi 87-1127 du 31 décembre 1987.

${ }^{24}$ We have voluntarily excluded criminal cases, which are too different to be compared with civil and administrative cases. Indeed, once a case goes to the criminal courts in France, then it will not be examined in the civil courts. This can be different from countries where a same case can go both to criminal and civil courts.
} 
environmental damage, environmental risk, environmental loss, ecological risk, ecological loss, ICPE ${ }^{25}$ Seveso, IPPC, ${ }^{26}$ and risk prevention. We obtained a total of 614 different cases, among which one fourth originated from the Conseil d'État. ${ }^{27}$

In the following subsections, we present the variables of interest and a set of control variables. All variables are dummy variables encoded " 1 " when present in cases and " 0 " otherwise.

The dependent variable is the decision of the court ("pro-defendant decisions", designated as Prodef), equal to 1 when judges rule in favor of the defendant and 0 otherwise. This variable measures the defendants' chances of success.

Among the explanatory variables, the identity of the court is the main variable of interest. It is designated as $C E$, and takes value 1 if the case is judged by the Conseil d'État and 0 if litigated by the Cour de Cassation. The econometric analysis relies heavily on this variable in order to determine whether the court's identity influences the outcome of the appeal, and thus, whether the correction behavior differs between the courts.

In order to take into account the specificity of each case, we use various control variables. The most important is the identity of the petitioner, designated as Defappeal, taking value 1 if the defendant filed the appeal before the supreme court and 0 if the victim did so. ${ }^{28}$ From a statistical viewpoint, this variable coefficient measures the judges' tendency to satisfy the party who files the appeal, whoever the party is. ${ }^{29}$ This variable provides some control over the "confirmative/validating" versus "invalidating" behavior of the court. This variable has to be taken into consideration. Indeed, in our database, $63.52 \%$ of the cases are filed by defendants and $36.48 \%$ by plaintiffs. An "invalidating" behavior will have a significant positive effect on the variable Prodef, whereas a "confirmative" behavior will have a significant negative effect on Prodef.

Environmental lawsuits may be brought for different reasons. Legal grounds describe the legal basis used by the petitioner to get her case to the Cour de Cassation or the Conseil d'État. In our database, we observe five different and recurrent legal grounds invoked by the petitioners: disagreement as to the amount of compensation (which we take as our reference variable), disagreement as to the relevance of the proof of wrongful or negligent behavior (Proof), disagreement with the appellate court's treatment of causation (Causality), disagreement with the appellate court's treatment of uncertainty about the consequences - in the case of a lawsuit primarily brought by potential victims claiming that a given activity imposes an imminent risk of

\footnotetext{
${ }^{25}$ Environmentally protected installations (Installations classées pour la protection de l'environnement).

${ }^{26}$ For Integrated Pollution Prevention and Control. See European Directive EC 96/61 imposing the application of the "Best Available Technology" principle to polluting facilities.

${ }^{27}$ We have 473 decisions of the Cour de Cassation the and 141 of the Conseil d'État.

${ }^{28}$ In our database, there is only one appellant for each case.

${ }^{29}$ Indeed, the coefficient of the variable Defappeal measures the probability $\operatorname{Pr}$ (Pro-defendant|Defendant appeal), which is the probability that Prodef takes value 1 when Defappeal changes from 0 to 1 . Defappeal takes value 1 when the defendant files the appeal and 0 when it is the plaintiff, and Prodef takes value 1 when the defendant wins and 0 when the plaintiff wins. Hence, observing the chances that the Prodef equals 1 when Defappeal changes from 0 to 1 is equivalent to measuring the chances that Prodef equals 0 when Defappeal changes from 1 to 0 . This amounts to observing the probability $\operatorname{Pr}$ (Pro-plaintiff|Plaintiff appeal), meaning the probability of having a pro-plaintiff decision when the plaintiff appeals. To be fully convinced: $\operatorname{Pr}($ Prode $f=1 \mid$ Defappeal $=1)-\operatorname{Pr}(\operatorname{Prode} f=1 \mid$ Defappeal $=$ $0)=[1-\operatorname{Pr}($ Prodef $=0 \mid$ Defappeal $=1)]-[1-\operatorname{Pr}($ Prodef $=0 \mid$ Defappeal $=0)]=\operatorname{Pr}($ Prodef $=0 \mid$ Defappeal $=$ $0)-\operatorname{Pr}($ Prodef $=0 \mid$ Defappeal $=1)$.
} 
accident - (Uncertainty), and disagreement as to the due process of law, or as to the legal procedure followed by the appellate court (Procedure).

Environmental lawsuits may also concern different natural assets. Another group of control variables identifies the type of natural resource affected: Water, Soil, Air, Sea, or Noise.

Lastly, a variable takes into account the fact that the defendant had complied with the regulation at the date of accident: Compliance with the regulation is a dummy variable, noted 1 if the defendant complied with the regulation and 0 otherwise. ${ }^{30}$

\section{Pro-plaintiff correction activities and case selection}

The empirical goal is twofold. First, we seek to determine whether the two supreme courts engage in the same level of correction activities. Second, we investigate the impact of case selection on these correction activities.

\subsection{Bias correction activities by supreme courts}

As stated in Section 2, the main objective of supreme courts is to ensure that legal provisions are enforced in the same way nationwide. Standard literature in Law and Economics usually refers to two kinds of mistakes judges can make when deciding a case. Type 1 errors correspond to cases where an innocent party is wrongfully convicted, whereas Type 2 errors refer to cases in which a guilty party gets away with it. As both kinds of errors are almost inevitable, the trade-off between the two types of errors is usually determined by the preferences of the court. These preferences can be expressed on a single dimension, i.e. a pro-defendant dimension. A pro-defendant court is less likely to convict a defendant when the evidence is mixed.

In the following analysis, we propose to consider the relative pro-defendant preferences of the appellate and supreme courts. We denote $\gamma$ the pro-defendant bias, with $\gamma \in(-\infty,+\infty)$. A higher $\gamma$ represents a stronger pro-defendant bias. Here, we understand the notion of bias in a very broad sense: it corresponds to the overall propensity of a court to decide in favor of the defendant when a case is unclear. We write $\gamma_{1, C}$ the average bias of the appellate courts in the civil jurisdictions, $\gamma_{2, C}$ the bias of the Cour de Cassation (i.e. the supreme civil court), $\gamma_{1, A}$ the average bias of the administrative appellate tribunals, and $\gamma_{2, A}$ the bias of the Conseil d'État (i.e. the supreme administrative tribunal).

The correction activities of each supreme court correspond to the decisions it takes to correct for the relative bias of the appellate courts. The differences in biases between the appellate and the supreme courts are given by:

$$
\Delta_{k}=\gamma_{1, k}-\gamma_{2, k}
$$

\footnotetext{
${ }^{30}$ For a detailed description of each variable, see Bentata (2013a), Bentata (2013b).
} 
where $k \in\{A, C\}$. The correction activities of the supreme courts in favor of the plaintiff are given by $h\left(\Delta_{k}\right)$, where $h($.$) is an increasing and monotonous function, and equal to zero at the$ origin. A positive $\Delta_{k}$ reflects a greater bias toward the defendant of the appellate court than the supreme court's bias. A positive $\Delta_{k}$ is therefore associated with more correction activities in favor of the plaintiff, i.e. positive values of $h\left(\Delta_{k}\right)$. Because supreme courts have been able to select cases at different dates, we introduce a conditional level of correction activity $h\left(\Delta_{k} \mid S_{k}\right)$ for a given selection rule $S_{k}$. A score $S_{k}=0$ indicates that supreme court $k$ has no control over its dockets, while $S_{k}=1$ reflects the fact that it can select cases.

Although our data do not allow us to locate each $\beta_{1, k}$ or $\beta_{2, k}$ on a pro-defendant axis, our empirical strategy aims at comparing the correction activities of the two courts. Three cases can emerge:

- Case 1. $h\left(\Delta_{C} \mid S_{A}=S_{C}\right)>h\left(\Delta_{A} \mid S_{A}=S_{C}\right)$ : The Cour de Cassation engages in more proplaintiff correction activity than the Conseil d'État.

- Case 2. $h\left(\Delta_{C} \mid S_{A}=S_{C}\right)=h\left(\Delta_{A} \mid S_{A}=S_{C}\right)$ : supreme courts engage in similar levels of pro-plaintiff correction.

- Case 3. $h\left(\Delta_{C} \mid S_{A}=S_{C}\right)<h\left(\Delta_{A} \mid S_{A}=S_{C}\right)$ : The Cour de Cassation engages in less proplaintiff correction activity than the Conseil d'État.

\subsection{Econometrics}

This subsection aims at testing the relative levels of correction activities depicted above. The goal is to determine whether courts engage in different levels of pro-plaintiff correction. To do so, we propose to run a Probit model to estimate the probability of a case being determined in the supreme court in favor of the plaintiff. The latent utility model we consider is written:

$$
\operatorname{Prodef}_{i}^{*}=\beta_{0}+\beta_{1} C E_{i}+\beta_{2} X_{i}+u_{i}
$$

where Prode $f^{*}$ is the latent utility of a pro-defendant decision, $C E_{i}$ is a variable equal to 1 if case $i$ is ruled by the Conseil $d^{\prime} E t a t, X_{i}$ is a vector of control variables for the case $i$, and $u_{i}$ is a normally distributed random term.

We propose to run the Probit model for four samples. First, we consider the entire set of data, running from 1956 to 2011. Second, because of the two reforms that introduced the possibility of case selection by supreme courts, we consider three periods in turn: when neither of the courts can select cases (1956 - 1989), when only the Conseil d'État is able to select cases (1988 - 2001), and when both courts are able to select cases (2002 - 2011). Results of these estimations are displayed in Table $1 .{ }^{31}$

\footnotetext{
${ }^{31}$ Estimations of the coefficients associated to the control variables are displayed in the Appendix.
} 
The objective of the Probit estimation consists in comparing the level of correction activities of the two courts. A positive (resp. negative) coefficient associated to $C E$ indicates that the Conseil $d^{\prime}$ État engages in less (resp. more) pro-plaintiff correction than the Cour de Cassation: case 1 (resp. case 3). A coefficient not statistically different from zero depicts a situation in which supreme courts have the same intensity of pro-plaintiff correction activities.

Table 1: Results of the Probit regressions

\begin{tabular}{|c|c|c|c|c|c|c|}
\hline & $\begin{array}{l}\text { Full Period } \\
\text { Model (1) }\end{array}$ & $\begin{array}{l}\text { Before } 1989 \\
\text { Model (2) }\end{array}$ & $\begin{array}{c}\text { From } 1989 \text { to } 2001 \\
\text { Model (3) }\end{array}$ & $\begin{array}{l}\text { After } 2001 \\
\text { Model (4) }\end{array}$ & $\begin{array}{l}\text { Full Period } \\
\text { Model (5) }\end{array}$ & $\begin{array}{l}\text { Full Period } \\
\text { Model (6) }\end{array}$ \\
\hline Conseil d'État (CE) & $\begin{array}{l}-0.274^{*} \\
(0.147)\end{array}$ & $\begin{array}{l}-0.152 \\
(0.258)\end{array}$ & $\begin{array}{c}-0.720^{* * *} \\
(0.272)\end{array}$ & $\begin{array}{l}-0.312 \\
(0.351)\end{array}$ & & \\
\hline $\mathrm{CE} \times \mathbb{1}_{t<1989}$ & & & & & $\begin{array}{l}-0.0595 \\
(0.234)\end{array}$ & \\
\hline$C E \times \mathbb{1}_{1989 \leq t \leq 2001}$ & & & & & $\begin{array}{c}-0.725^{* * *} \\
(0.268)\end{array}$ & $\begin{array}{c}-0.724^{* * *} \\
(0.268)\end{array}$ \\
\hline$C E \times \mathbb{1}_{2001>t}$ & & & & & $\begin{array}{l}-0.193 \\
(0.337)\end{array}$ & \\
\hline $\mathrm{CE} \times\left(1-\mathbb{1}_{1989 \leq t \leq 2001}\right)$ & & & & & & $\begin{array}{l}-0.104 \\
(0.191)\end{array}$ \\
\hline Observations & 614 & 168 & 276 & 169 & 614 & 614 \\
\hline Nagelkerke $R^{2}$ & 0.395 & 0.432 & 0.466 & 0.342 & 0.395 & 0.395 \\
\hline
\end{tabular}

Table 1 yields interesting results. At first sight, the estimation in model 1 suggests that the Conseil d'État (supreme administrative tribunal) engages in more pro-plaintiff correction activities than the Cour de Cassation (supreme civil court). Indeed, the coefficient associated to $C E$ is statistically different from zero in this regression covering the entire period. Decomposing the data into three sub-periods yields additional results. First, in model 2, i.e. prior to 1989, when neither supreme court could select cases, we do not detect any difference in the intensity of the correction activities of the courts. Second, in model 4, after 2001, when both supreme courts were able to select cases, we do not detect any difference between their correction activities. Third, one can note, however, a highly significant difference in the correction activities in model 3, i.e. between 1989 and 2001, when only the Conseil d'État could select cases.

In the appendix, we run two additional regressions, namely models 5 and 6 . Running separate regressions to estimate the marginal impact of the Conseil d'État for each subperiod is the most intuitive -and the most commonly used- method. However, if one assumes that the control variables have a similar impact on the decision whatever the period at stake, it is more efficient to estimate the model on a single sample and to distinguish the marginal effect of the variable of interest with interaction with dummy variables. Models 5 and 6 confirm the findings of models 2 to $4 . .^{32}$

\footnotetext{
${ }^{32}$ With model 6, we investigate whether the marginal effect of $C E$ is different when courts have the same control possibilities over their dockets and when they have not. We reject this hypothesis with $p=0.060$. We believe that the
} 
Table 2: Marginal Effects of Model 5 from table 1

\begin{tabular}{lcccc}
\hline \hline Variable & Marginal Effect & P-value & Lower Bound & Upper Bound \\
\hline$C E \times \mathbb{1}_{t<1989}$ & -0.0059 & 0.953 & -0.2018 & 0.1900 \\
$C E \times \mathbb{1}_{1989 \leq t \leq 2001}$ & $-0.2839^{* *}$ & 0.019 & -0.5221 & -0.0457 \\
$C E \times \mathbb{1}_{2001>t}$ & -0.1081 & 0.446 & -0.3860 & 0.1698 \\
\hline \hline
\end{tabular}

Finally, we compute the marginal effects associated to model 5 in order to investigate whether the absence of significance associated to the first (i.e., before 1989) and last periods (i.e., after 2001) result from higher incertitude in the estimation or from a lower estimated effect. Table 2 displays the marginal effect associated with the Conseil d'État for each subperiod. As one can see, the effect is the strongest $(-28.4 \%)$ between the two reforms and the lowest before $1989(-0.6 \%)$. The average marginal effect associated to the Conseil d'État is almost three times lower after the second reform enters in force $(-10.8 \%)$. This indicates that the lack of significance after 2001 does not solely result from the incertitude in the estimation but from the estimated magnitude itself that is much lower.

The results can be summarized as follows:

- Over the entire period, we observe a stronger commitment of the Conseil d'État than the Cour de Cassation to correct the pro-defendant bias of the appellate courts.

- This effect is driven by the fact that the Conseil d'État was allowed to select cases earlier, between 1989 and 2001, and used case selection to increase its pro-plaintiff correction activities.

- When both courts were (or when neither court was) allowed to select cases, we do not detect any difference in their correction activities.

Hence, it appears that although administrative judges have a background that may lead to a pro-defendant bias, correction activities of both supreme courts are similar, which could be interpreted as follows: there is no difference between administrative and civil supreme courts' judges' perception regarding how administrative and civil judges from lower courts interpret legal rules. In other words, the fact that judges from the Conseil d'Etat do not engage in more pro-plaintiff correction activity than judges from the Cour de Cassation does not imply that administrative judges are not subject to a pro-defendant bias but rather that judges from the Conseil $d^{\prime}$ Etat do not perceive a more important pro-defendant bias at lower administrative courts' level than judges from the Cour de Cassation at lower civil courts' level.

In order to evaluate the veracity of these propositions, we propose several additional investigations. First, to compare the difference in the correction activities between the supreme courts, we

weak significance mainly results from the low number of observations. All in all, these two additional regressions confirm our main results. 
create counterfactual cases using one court's decisions to predict the other court's ones (Subsection 5.3). Second, we use permutation tests to ensure that the change in the correction activities is indeed driven by the two reforms and not by actual changes in the supreme courts' preferences between 1989 and 2001 (Subsection 5.4).

\subsection{Counterfactuals}

In order to compare the correction activities of the courts, and thus to confirm or invalidate the previous results, we propose to adopt a counterfactual approach. The objective consists in creating cases using one supreme court's decisions to predict the other supreme court's ones, and to capture the discrepancies between the predictions and the observations. To do so, we rely on matching methods.

The underlying idea of matching estimations is to sort observations from two groups on a single axis (the balancing score), such that units with comparable scores from the two groups share the same observables (Rosenbaum and Rubin (1983)). The subsequent theoretical and applied literature has mainly used the propensity score, i.e. the probability of belonging to one group or another, as a balancing score (Rosenbaum and Rubin (1984)). We proceed in the same way and propose to use a case's probability of being determined by the Conseil d'État as a balancing score.

We estimate the following equation to compute the balancing score:

$$
\mathrm{CE}_{i}^{*}=\alpha_{0}+\alpha_{1} X_{i}+v_{i}
$$

where $X_{i}$ is the same vector of control variables as in equation (2) and $v_{i}$ is a normally distributed random term.

We estimate equation (3) for three periods: before 1989, between 1989 and 2000, and after 2001. We then use matching algorithms to create counterfactuals. We take the cases reviewed by the Conseil d'État as the reference group, and we use matching algorithms to create, for each case, counterfactuals that are combinations of the cases dealt with by the Cour de Cassation. We use four algorithms: the nearest neighbor, the 3-nearest neighbors, the Epanechnikov kernel, and the Normal kernel.

Table 3 displays the average bias associated with each matching algorithm and the original standardized bias. As can be seen, the Epanechnikov outperforms the other algorithms and dramatically reduces the biases. The Gaussian (or Normal) kernel performs well too, but is slightly above the $5 \%$ threshold for the average standardized bias. We thus build the counterfactuals based on the Epanechnikov and Gaussian kernels.

For each case $i$ of the Conseil d'État we compute a counterfactual case, i.e. a linear combina- 
Table 3: Matching diagnosis: average standard bias per matching algorithm

\begin{tabular}{lccc}
\hline \hline & Before 1989 & From 1989 to 2001 & After 2001 \\
\hline Before matching & 9.713 & 19.787 & 23.459 \\
Nearest Neighbor & 10.762 & 7.724 & 6.376 \\
3-nearest neighbors & 10.93 & 6.171 & 6.554 \\
Epanechnikov kernel & 3.99 & 2.463 & 3.469 \\
Gaussian kernel & 4.664 & 5.208 & 3.693 \\
\hline \hline
\end{tabular}

tion of the cases of the Cour de Cassation. We then compute the difference between the actual decision of the Conseil d'État and the probability of a pro-defendant decision predicted by the counterfactual. If the latter were a correct estimation of the real probability of a pro-defendant decision, the average difference between the actual and the predicted decisions should be close to 0 . On the contrary, a systematic deviation, i.e. over- or underestimation, would reflect the higher propensity of one court to rule in favor of one party relative to the other court.

Table 4 reports the average difference between the predicted and actual decisions of the courts for each of the three periods. It also shows whether these average differences are statistically different from 0 .

Table 4: Average differences between the actual pro-defendant decisions of the Conseil d'État and the predictions based on the decisions of the Cour de Cassation.

\begin{tabular}{lccc}
\hline \hline & Before 1989 & From 1989 to 2001 & After 2001 \\
\hline Epanechnikov & -.0673 & $-.1520^{* *}$ & -.1073 \\
& $(-0.86)$ & $(-2.24)$ & $(-1.06)$ \\
Gaussian & -.0382 & $-.1792^{* * *}$ & -.0813 \\
& $(-0.50)$ & $(-2.72)$ & $(-0.82)$ \\
\hline \hline \multicolumn{4}{c}{ Note: Z-statistics, ${ }^{* * *} p<0.01,^{* *} p<0.05,^{*} p<0.1}$.
\end{tabular}

A few conclusions can be drawn from this second set of estimations. First, it confirms that both courts engage in the same level of pro-plaintiff correction activity when they face the same selection rule. ${ }^{33}$ Using the notation introduced in Subsection 5.1, this implies that $h\left(\Delta_{C} \mid S_{C}=\right.$ $\left.S_{A}\right)=h\left(\Delta_{A} \mid S_{C}=S_{A}\right)$. Second, regarding the correction activity of the courts between 1989 and 2001, the estimation concludes that $h\left(\Delta_{C} \mid S_{C, 0}\right)<h\left(\Delta_{A} \mid S_{A, 1}\right)$, indicating that the Conseil d'État increased its pro-plaintiff correction activity during this time period.

\subsection{Change in correction activity or change in preferences?}

There are two possible explanations for the previous results. First, they might be supported by our theory, which claims that courts have increased their correction activity through case selection. Second, they might alternatively be explained by a change in courts' preferences over

\footnotetext{
${ }^{33}$ According to our results, the introduction of a selection rule decreases by 15.2 to 17.9 percentage points the probability that the Conseil d'État will rule in favor of the defendant. Yet, the figures have to be taken with caution as they are derived from a linear probability model.
} 
time: our data would lead to the same conclusions if the Conseil d'État changed its views in the 1980s, and the Cour de Cassation changed its own in the late 1990s.

In order to investigate this issue, we propose several tests to ensure that our results are indeed driven by the two specific dates 1989 and 2001. Although we are unable to rule out the possibility that upper instances changed their preferences at the precise moment when they obtained case selection, we are willing to exclude the possibility that supreme courts changed their position steadily over time. To do so, we propose two falsification tests. First, we permute the reform status in the data. Second, we look at the outcome if we artificially set the reform five years before or five years after the actual reform.

Permutation test. The first test deals with the null hypothesis that, in each court, the impact of the reform on the win rates of defendants (Prodef) is random. The underlying intuition for this test is that if the effect of the reform is random, then a random reallocation of the reform date should have a similar or greater effect on the variable Prodef.

For each court, we create a variable Reform taking value 1 if the case is reviewed after the reform and 0 otherwise. We observe the effect of the reform on the variable Prodef using an OLS regression on a period extending from ten years before the reform to ten years after the reform (we keep all the control variables, as we did for the other regressions). For both courts, the variable Reform is significant with a negative coefficient $(\beta=-0.163$ and $p=0.088$ for the Conseil d'État, $\beta=-0.115$ and $p=0.024$ for the Cour de Cassation).

We permute the variable Reform: we randomly reallocate the values of the variable Reform in the sample of interest and observe the effect of this random variable (denoted $x$ on Figure 1) on the results. We repeat this operation 5000 times and compare the distribution of the coefficients of the random variable (denoted $b$ in Figure 1) with the coefficient of the variable Reform. Under the null hypothesis, the coefficient of Reform is regularly found in the distribution ( $p$-value $>0.05$ ): we cannot reject the assumption that the effect of the reform is simply random.

Figure 1 shows the results of permutations for both courts. We observe that the value of the coefficient of the variable Reform is always in the extreme $5 \%$ of the normal distribution. The probability of obtaining an identical coefficient at random is $p-v a l u e=0.0146$ for the Conseil $d^{\prime}$ État and $p-v a l u e=0.0032$ for the Cour de Cassation .

We thus reject $H_{0}$ : the above results are not driven by the random character of the data but by the reforms.

- Falsification of reform dates. Although the reform has a significant effect on the observed outcome, we may wonder whether this effect is simply the result of a variation in the severity of judges over the same period, i.e. a variation in upper instances' preferences. In order to ensure that this is not the case, we observe, for each court, the evolution in the severity of judges starting at a previous or later date with respect to the reform: we measure the effect of a temporal variable starting five years before then five years after the actual reform on the variable Prodef. For the Cour de Cassation, we thus measure the effects of two temporal variables, one starting in 1997 and the other in 2007, and compare the coefficients obtained with those of the variable 


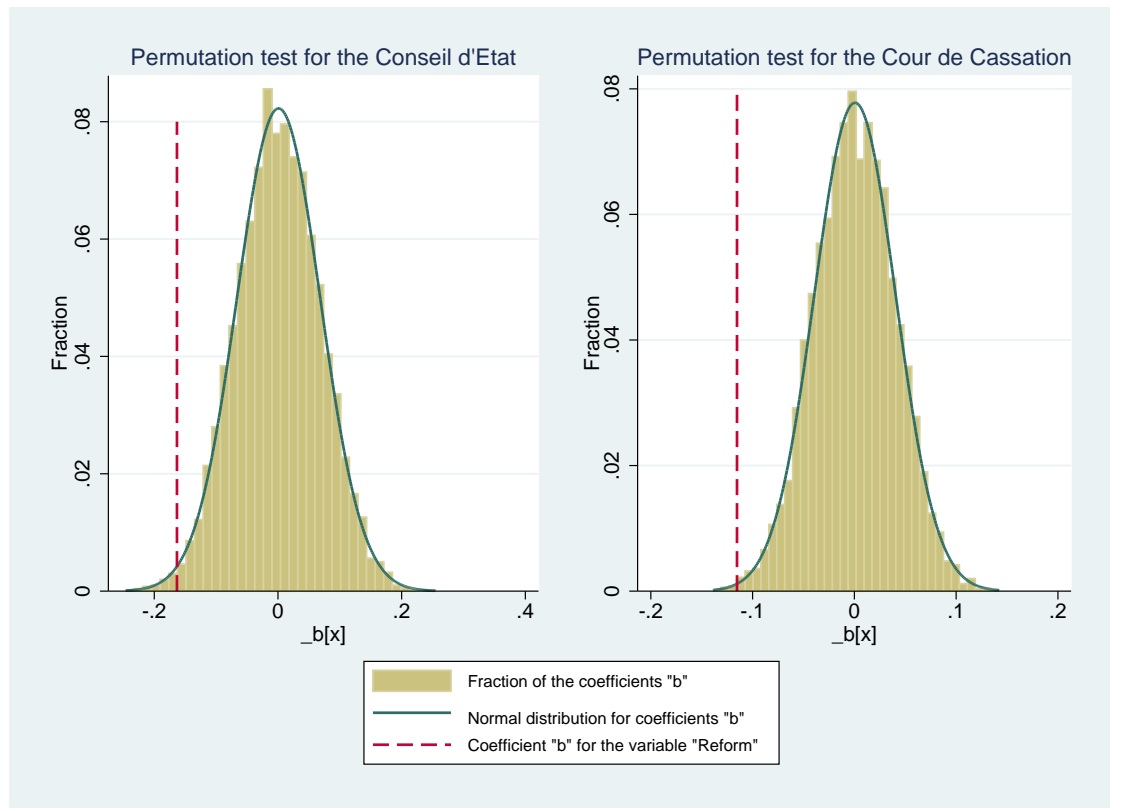

Figure 1: Graphic results for the falsification tests with permutation

Reform. For the Conseil d'État, we do the same with a variable starting in 1984 and the other in 1994. Table 5 provides the results for both courts.

Table 5: Comparison of different time periods over judges' decisions

\begin{tabular}{lccc}
\hline \hline & Reform & Reform minus 5 years & Reform plus 5 years \\
\hline Cassation & $-0.12^{* * *}$ & -0.06 & $-0.10^{*}$ \\
& $(0.01)$ & $(0.04)$ & $(0.05)$ \\
\hline Conseil d'État & $-0.14^{* *}$ & -0.06 & $-0.12^{*}$ \\
& $(0.07)$ & $(0.08)$ & $(0.07)$ \\
\hline \hline
\end{tabular}

Note: Standard errors in parentheses, ${ }^{* * *} p<0.01,{ }^{* *} p<0.05,{ }^{*} p<0.1$. The set of control variables used throughout the paper is also used in these regressions. The falsification tests are conducted separately for each type of courts.

We observe that the temporal variables starting before the reform are non-significant; those starting after the reform have a slightly weaker effect than the reform itself. Hence, for both courts, the variation in the severity of judges actually starts with the reform. This confirms the above findings supporting the reform's effect.

\subsection{How do courts select their dockets?}

The previous subsections have highlighted the existence of correction activities from both courts, that induce lower win rates for defendants before these courts. Such a correction activity can materialize in two ways: either judges select appeals filed by defendants and uphold lower courts' decisions, or they select appeals filed by plaintiffs and reverse appellate courts' decisions. The two selection modes have different effects on the trial outcome: 
- Scenario 1. With the first strategy, the correction activity has a limited effect on the trial outcome. Indeed, the highest instances preferably select appeals filed by defendants (i.e. judgments in favor of plaintiffs in appellate courts) and uphold appellate courts' decisions, while often declaring as "non-eligible" the appeals filed by plaintiffs (i.e. judgments in favor of defendants in appellate courts). Hence, supreme instances essentially select cases in order to uphold appellate courts' decisions and the correction activity does not alter the outcome of the trial. From a legal viewpoint, the correction activity has "no influence" on final decisions.

- Scenario 2. With the second strategy, the correction activity has a decisive effect on the trial outcome. Supreme instances preferably select appeals filed by plaintiffs (i.e. judgments in favor of defendants in appellate courts) and reverse appellate courts' decisions, while often declaring as "non-eligible" the appeals filed by defendants (i.e. judgments in favor of plaintiffs in appellate courts). As a consequence, appellate courts' decisions are reversed more often in favor of plaintiffs. From a legal viewpoint, the correction activity modifies the trial outcome in favor of plaintiffs.

In order to determine the selection process of supreme instances, we observe the influence of the reforms in the Conseil d'État and the Cour de Cassation over their decisions to reverse appellate courts' decisions. For this purpose, we build a dummy variable (Reverse), taking value 1 when the appellate court's decision has been reversed and 0 otherwise. We carry out a Biprobit regression with the dependent variables Reverse and Prodef. Indeed, whatever the selection mode (Scenario 1 or Scenario 2), the decision to reverse or uphold a judgment is clearly correlated with the identity of the winning party. We also introduce an interaction variable (Defappeal*Reform) allowing us to observe the effect of a defendant appealing after the reform on the probability of a judgment reversal. Last, we keep the whole set of previous control variables. Table 6 depicts the results of the regression.

In order to capture the selection strategy of supreme instances, we focus on the variable Reverse. In each court, the reform significantly increased the chances of a reversal decision. Hence, it seems that the supreme courts often select cases in order to counter appellate courts' decisions. Besides, the interaction variable Defendant appeal ${ }^{*}$ Reform has a significant and negative effect on reversals. In other words, it seems that the supreme courts select cases in order to counter appellate courts' decisions, particularly when the latter are unfavorable to the plaintiffs: defendants have fewer chances of obtaining a reversal after the reform, though the overall chances of a reversal have increased. The selection bias thus clearly affects the overall trial outcome: courts more often select cases that they will counter in favor of plaintiffs (Scenario 2).

These results suggest an overall interpretation concerning the impact of the correction activity over the win rates of the litigants. A losing plaintiff (resp. defendant) in appellate courts has relatively more chances than a defendant (resp. fewer chances than a plaintiff) of seeing her case admitted by supreme instances and of obtaining a reversal of the appellate courts' decision. In other words, the pro-plaintiff effect observed when analyzing supreme courts is not a simple statistical artefact giving a truncated description of the whole set of courts' decisions. It is a genuine bias which modifies the actual win rates of litigants in favor of plaintiffs. 
Table 6: Results of the Biprobit regression on Reverse and Pro-defendant

\begin{tabular}{lcc}
\hline \hline & Reverse & $\begin{array}{c}\text { Coefficients } \\
\text { Pro-defendant }\end{array}$ \\
\hline \multirow{3}{*}{ Reform in CE } & $0.485^{* *}$ & $-0.825^{* * *}$ \\
& $(0.245)$ & $(0.258)$ \\
Reform in CC & $0.403^{* *}$ & $-0.573^{* * *}$ \\
& $(0.193)$ & $(0.200)$ \\
Def appeal Reform & $-0.769^{* * *}$ & 0.279 \\
& $(0.245)$ & $(0.256)$ \\
Defendant appeal & $-0.276^{*}$ & $-1.194^{* * *}$ \\
& $(0.145)$ & $(0.149)$ \\
Athrho & & $0.227^{* * *}$ \\
& & $(0.072)$ \\
Controls & \multicolumn{2}{c}{ Yes } \\
Observations & \multicolumn{2}{c}{614} \\
\hline \hline Note. Standard errors in parentheses, ${ }^{* * *} p<0.01,{ }^{* *} p<0.05,{ }^{*} p<0.1$.
\end{tabular}

\section{Conclusion}

In this paper, we have adopted two different approaches (linear regressions and matching estimation) in order to distinguish and quantify the effects of bias correction activities and selection biases of France's two supreme courts. Our study shows that both the supreme administrative and civil courts correct appellate courts' decisions in the same direction and in the same magnitude: both supreme courts are indeed more favorable towards plaintiffs than their respective appellate courts. We have also shown that the correction activities of the supreme courts are similar when both have the same selection mechanism over their dockets, i.e. administrative judges' decisions are not perceived by judges from the Conseil d'Etat as more biased than civil judges' decisions by judges from the Cour de Cassation. Finally, we find that this result is driven by the selection strategies of the supreme courts, which are more likely to select cases that they will overrule in favor of the plaintiffs. Indeed, our last results show that the supreme courts select cases in order to counter appellate courts' decisions (i.e., increased probability of reversal), particularly when the latter are unfavorable to the plaintiffs.

Our results have several implications for the public and academic debates on the role of supreme courts. First, one can observe that both courts engage in the same level of correction activity and that the correction goes in the same direction (pro-plaintiff correction). This result implies that both branches of the French legal system are similar in terms of the relative biases between supreme courts and their respective appellate courts, i.e. administrative judges from appellate courts do not seem to be subject to any specific pro-defendant bias. In both branches, plaintiffs face the same incentives to bring their claim to the highest court. Second, as far as the selection mechanism is concerned, we observe that preventing courts from selecting cases puts great pres- 
sure on them. Indeed, the great increase in the probability of a pro-plaintiff decision resulting from the selection rule shows the readiness of the courts to select cases and fully exercize their correction activities. Regarding the harmonization of the legal system, giving supreme courts control over their dockets might improve legal efficiency: their effective correction activity sends signals to appellate courts. This finding is especially important in the perspective of judicial reforms undertaken in other countries. Indeed, some supreme courts have recently experienced similar changes (Taiwan in the early 2000s, ${ }^{34}$ Brazil in 2007) and could be followed by others since the backlog of cases before the courts and the resulting delays are a wide-spread public policy problem.

Our investigation is nevertheless limited in several ways. An obvious limitation concerns case selection: cases, which are brought by litigants to supreme courts, might not be representative of the entire set of cases dealt with by appellate courts. We therefore ignore whether supreme courts determine representative cases or exceptional ones. Investigating the entire set of cases brought to lower or appeal courts could help understanding the relevance of the Supreme Courts' decisions. However, the investigation of the comprehensive set of decisions is, to our knowledge, limited in France by the availability of data. Second, still regarding the appeal process, it might be that the unobservable variables influencing the decision to bring the case to the supreme court are correlated with the unobservable variables influencing the supreme courts' decisions. Ignoring the correlation between these two decisions may lead to a flawed estimation of the covariance matrix of our estimated coefficients, leading to "mistaken" inferences. A remedy could be to consider the entire set of cases that were appealed to the Supreme Court to understand the selection mechanism and to correct the subsequent inferences. Third, we are limited in investigating the impact of the reform on supreme courts' behaviors: we do not have the pool of cases which have been denied any hearing by the supreme courts. Here again, unobserved factors leading supreme courts to hear a case are very likely to explain their final decision. Changes in strategies of litigants to bring their case to the supreme court, or anticipation by Appeal Courts of the new institutional framework, are two main elements future research should seek to take into account. Here again, a solution would consist in considering all appeal courts' decision to determine litigants' strategies and the associated changes following the reform.

\section{References}

Amaral-Garcia, S. and Garoupa, N. (2012). Do Administrative Courts Favor the Government? Evidence from Medical Malpractice in Spain. 7th Annual Conference on Empirical Legal Studies.

Amaral-Garcia, S., Garoupa, N., and Grembi, V. (2009). Judicial Independence and Party Politics in the Kelsenian Constitutional Courts: The Case of Portugal. Journal of Empirical Legal Studies, 6(2):381-404.

\footnotetext{
${ }^{34}$ See Eisenberg et al. (2012)
} 
Ashenfelter, O., Eisenberg, T., and Schwab, S. J. (1995). Politics and the Judicary. Journal of Legal Studies, 24:257-281.

Bentata, P. (2013a). Environmental Regulation and Civil Liability under Causal Uncertainty: An Empirical Study of the French Legal System. Review of Law and Economics, 9(2):239-263.

Bentata, P. (2013b). Liability as a Complement to Environmental Regulation: An Empirical Study of The French Legal System. Environmental Economics and Policy Studies, 16(3):201-228.

Bentata, P. and Faure, M. G. (2012). The Role of Environmental Civil Liability: An Economic Analysis. Environmental Liability, 20(4):120-128.

Berger, H. and Neugart, M. (2011). Labor Courts, Nomination Bias, and Unemployment in Germany. European Journal of Political Economy, 27:659-673.

Bogoch, B. and Don-Yechiya, R. (1999). The Gender of Justice: Bias Against Women in Israeli Courts. Jerusalem Institute for Israel Studies (Hebrew).

Bornstein, B. H. and K., M. M. (2009). Does a Judge's Religion Influence Decision Making? Court Review: The Journal of the American Judges Association, 45(112-115).

Boyd, C. L., Epstein, L., and Martin, A. D. (2010). Untangling the Causal Effects of Sex on Judging. American Journal of Political Science, 54:389-411.

Choi, S. J. and Gulati, M. (2008). Bias in Judical Citations: A Window into the Behavior of Judges? Journal of Legal Studies, 37(1):87-129.

Choi, S. J., Gulati, M., Holman, M., and Posner, E. A. (2011). Judging Women. Journal of Empirical Legal Studies, 8(3):504-532.

Clermont, K. M. and Eisenberg, T. (1992). Trial by Jury or Judge: Transcending Empiricism. Cornell Law Review, 77:1124-1177.

Clermont, K. M. and Eisenberg, T. (1998). Do Case Outcomes Really Reveal Anything About the Legal System? Win Rates and Removal Jurisdiction. Cornell Law Review, 83:581-607.

Clermont, K. M. and Eisenberg, T. (2001). Appeal from Jury or Judge Trial: Defendants' Advantage. American Law and Economics Review, 3(1):125-164.

Clermont, K. M. and Eisenberg, T. (2002). Plaintiphobia in the Appellate Courts: Civil Rights really Do Differ from Negotiable Instruments. University of Illinois Law Review, pages 947-977.

Cross, F. B. (1997). Political Science and the New Legal Realism: A case for Unfortunate Interdisciplinary Ignorance. Northwestern University Law Review, 92(1):251-326.

Desrieux, C. and Espinosa, R. (2015). Conseils de Prud'hommes, Syndicats et Résolution des litiges : une analyse Économique. Les Cahiers de la Justice, (4):533-545.

Donohue, J. and Siegelman, P. (1990). Study the Iceberg From its Tip: A Comparison of Published and Unpublished Employment Discrimination Cases. Yale Faculty Scholarship Series Papers, 43. 
Eisenberg, T. (1990). Testing the Selection Effect: A New Theoretical Framework with Empirical Tests. Journal of Legal Studies, 19(2):337-358.

Eisenberg, T. (2004). Appeal Rates and Outcomes in Tried and Nontried Cases: Further Exploration of Anti-Plaintiff Appellate Outcomes. Journal of Legal Studies, 1(3):659-688.

Eisenberg, T. and Farber, H. S. (2003). The Government as Litigant: Further Tests of the Case Selection Model. American Law and Economics Review, 5(1):94-133.

Eisenberg, T. and Farber, H. S. (2013). Why do Plaintiffs Lose Appeals? Biased Trial Courts, Litigious Losers, or Low Trial Win Rates. American Law and Economics Review, 15(1):73-109.

Eisenberg, T., Fisher, T., and Rosen-Zvi, I. (2011). Israel's Supreme Court Appellate Jurisdiction: An Empirical Study. Cornell Law Review, 96:693-725.

Eisenberg, T., Fisher, T., and Rosen-Zvi, I. (2012). Does the Judge Matter? Exploiting Random Assignment on a Court of Last Resort to Assess Judge and Case Selection Effects. Journal of Empirical Legal Studies, 9(2):246-290.

Eisenberg, T., Fisher, T., and Rosen-Zvi, I. (2014). Case Selection and Dissent in Courts of Last Resort: An Empirical Study of the Israel Supreme Court. In Chang, Y.-C., editor, Empirical Legal Analysis: Assessing the Performance of Legal Institutions, pages 181-215. Routledge.

Eisenberg, T. and Heise, M. (2009). Plaintiphobia in State Courts? An Empirical Study of State Courts Trials on Appeal. Journal of Legal Studies, 38:121-137.

Eisenberg, T. and Huang, K.-C. (2012). The Effects of Rule Shifting Supreme Courts Decisions from Mandatory to Discretionary: An Empirical Lesson from Taiwan. International Review of Law and Economics, 32:3-18.

Epstein, L. and Martin, A. D. (2010). Does Public Opinion Influence the Supreme Court? Possibly Yes (But We're Not Sure Why). University of Pennsylvania Journal of Constitutional Law, 13(2):263-281.

Espinosa, R. (2015). L'indépendance du Conseil constitutionnel français en question. Les Cahiers de la Justice, (4):546-561.

Espinosa, R. (2017). Constitutional Judicial Behavior: Exploring the Determinants of the Decisions of the French Constitutional Council. Review of Law and Economics, 13(2).

Franck, R. (2009). Judicial Independence Under a Divided Polity: A Study of the Rulings of the French Constitutional Court, 1959-2006. Journal of Law, Economics and Organization, 25(1):262284.

Friedman, B. (2006). Taking Law Seriously. Perspective and Politics, 4(2):261-276.

Frydman, P. (2008). Administrative Justice in France. In 11th AIJA Tribunals Conference, Queensland, Australia. 
Gazal-Ayal, O. and Sulitzeanu-Kenan, R. (2010). Let My People Go: Ethnic In-Group Bias in Judicial Decisions: Evidence from a Randomized Natural Experiment. Journal of Empirical Legal Studies, 7(3):403-428.

Greiner, J. D. and Rubin, D. B. (2011). Causal Effects of Perceived Immutable Characteristics. The Review of Economics and Statistics, 93(3):775-785.

Hall, M. (2010). Randomness Reconsidered: Modeling Random Judicial Assignment in the U.S. Courts of Appeals. Journal of Empirical Legal Studies, 7(3):574-589.

Harvey, A. and Friedman, B. (2009). Ducking Trouble: Congressionally Induced Selection Bias in Supreme Court's Agenda. Journal of Politics, 71(2):574-592.

Ichino, A., Polo, M., and Rettore, E. (2003). Are Judges Biased by Labor Market Conditions? European Economic Review, 47:913-944.

Kastellec, J. P. and Lax, J. R. (2008). Case Selection and the Study of Judicial Politics. Journal of Empirical Legal Studies, 5(3):407-446.

Keele, D. M., Malmsheimer, R. W., Floyd, D. W., and Zhang, L. (2009). An Analysis of Ideological Effects in Published Versus Unpublished Judicial Opinions. Journal of Empirical Legal Studies, 6(1):213-239.

Kritzer, H. M. and Richards, M. J. (2002). Deciding the Supreme Court's Administrative Law Cases: Does Chevron Matter? In Annual Meeting of the American Political Science Association. Boston, MA.

Lambert-Mogiliansky, A., Sonin, K., and Zhuravskaya, E. (2006). Are Russian Commercial Courts Biased? Evidence from a Natural Bankruptcy Experiment. CEPR Discussions Paper 5998.

Law, D. S. (2005). Strategic Judicial Lawmaking: Ideology, Publication, and Asylum Law in the Ninth Circuit. University of Cincinnati Law Review, 73(3):817-865.

Macis, M. (2001). Il Mercato del Lavoro e la Giurisprudenza in Materia di Licenziamenti (Italia 1989-1998). Diritti delle Relazioni Industriali, 2.

Malo, M., Martin-Roman, A., and Moral, A. (2016). "Peer effects" or "quasi-peer effects" in Spanish labour court rulings. MPRA Paper 72669.

Marinescu, I. (2003). L'application du droit du travail est-elle biaisée par les conditions économiques? Paper for the ADRES conference in Paris.

Marinescu, I. (2011). Are Judges Sensitive to Economic Conditions? Evidence from U.K. Employment Tribunals. Industrial and Labot Relations Review, 64(4):673-698.

Martin, A. D., Quinn, K. M., and Epstein, L. (2005). The Median Justice on the United States Supreme Court. North Carolina Law Review, 83(5):1275-1320. 
Merritt, D. J. and Brudney, J. J. (2001). Stalking Secret Law: What Predicts Publication in the United State Courts of Appeals. Vanderbilt Law Review, 54:71-121.

Priest, G. L. and Klein, B. (1984). The Selection of Disputes for Litigation. Journal of Legal Studies, 13:1-55.

Rosenbaum, P. R. and Rubin, D. B. (1983). The Central Role of the Propensity Score in Observational Studies for Causal Effects. Biometrika, 70(1):41-55.

Rosenbaum, P. R. and Rubin, D. B. (1984). Reducing Bias in Observational Studies Using Subclassification on the Propensity Score. Journal of the American Statistical Association, 79(387):516524.

Shavell, S. (1995). The Appeals Process as a Means of Error Correction. Journal of Legal Studies, 24:379-426.

Shayo, M. and Zussman, A. (2011). Judicial Ingroup Bias in the Shadow of Terrorism. Quarterly Journal of Economics, 126:1447.

Spiller, P. T. and Gely, R. (1992). Congressional Control or Judicial Independence: The Determinants of U.S. Supreme Court Labor-relations Decisions, 1949-1988. RAND Journal of Economics, 23(4):463-492.

Sunstein, C. R., Schkade, D., Ellman, L. M., and Sawicki, A. (2006). Are Judges Political? An Empirical Analysis of the Federal Judicary. Brookings Institution Press.

\section{Tables}

Table 7: Descriptive Statistics

\begin{tabular}{lcccc}
\hline \hline Variables & $\begin{array}{c}\text { All } \\
\text { Decisions }\end{array}$ & $\begin{array}{c}\text { CE } \\
\text { only }\end{array}$ & $\begin{array}{c}\text { CC } \\
\text { only }\end{array}$ & p-value \\
\hline Defendant appeal & 0.635 & 0.730 & 0.607 & 0.007 \\
Compliance & 0.539 & 0.489 & 0.554 & 0.177 \\
Compensation & 0.158 & 0.149 & 0.161 & 0.737 \\
Proof & 0.264 & 0.319 & 0.247 & 0.089 \\
Causality & 0.220 & 0.191 & 0.228 & 0.354 \\
Uncertainty & 0.153 & 0.128 & 0.161 & 0.339 \\
Procedure & 0.339 & 0.284 & 0.355 & 0.115 \\
Water & 0.350 & 0.369 & 0.345 & 0.598 \\
Soil & 0.171 & 0.163 & 0.173 & 0.777 \\
Air & 0.138 & 0.170 & 0.129 & 0.213 \\
Sea & 0.034 & 0.007 & 0.042 & 0.044 \\
Noise & 0.226 & 0.191 & 0.270 & 0.256 \\
\hline \hline Note: The p-values correspond to two-sample proportion tests.
\end{tabular}


Table 8: Full results of the Probit regressions

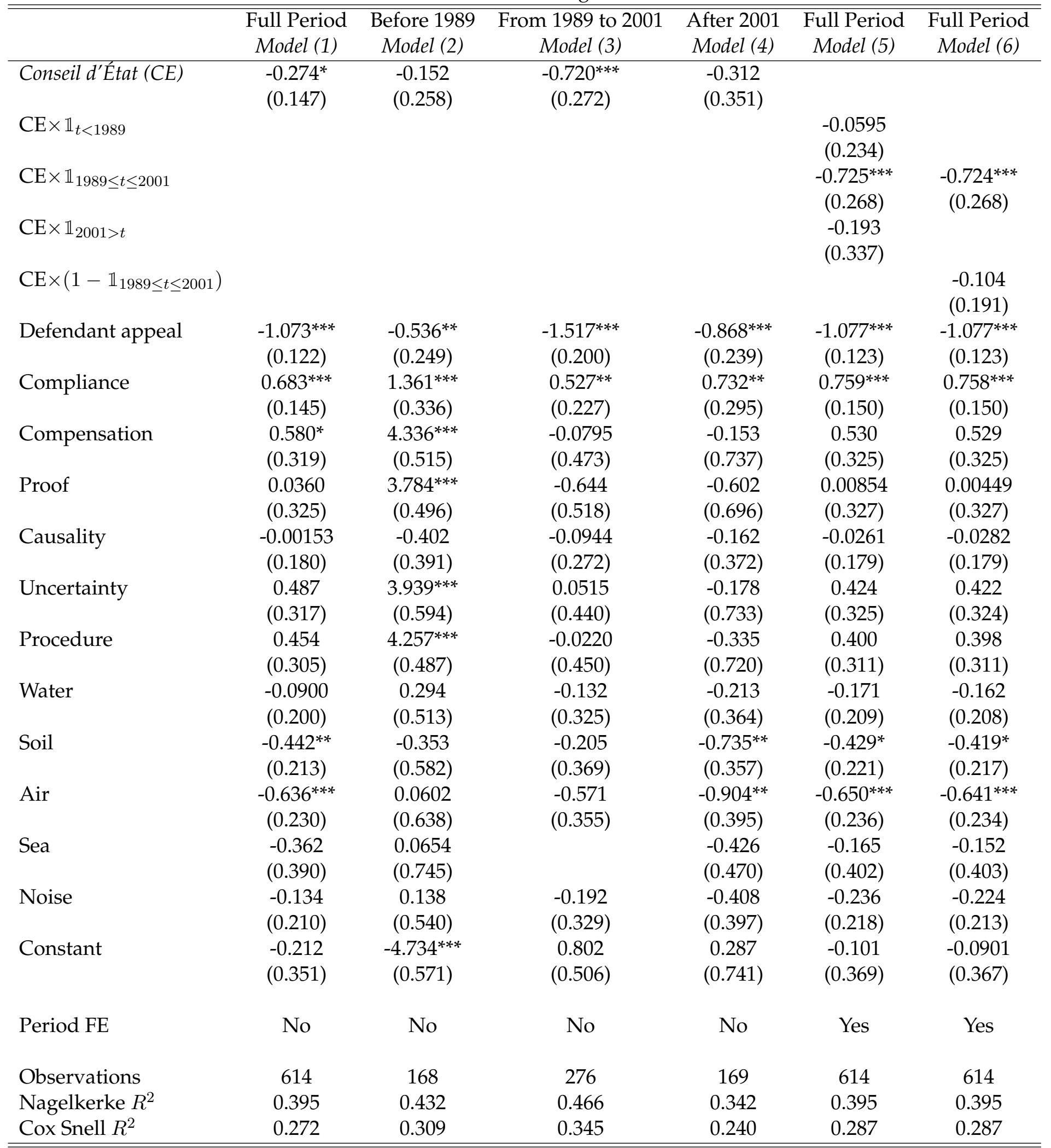

Note. Standard errors in parentheses, ${ }^{* * *} p<0.01,{ }^{* *} p<0.05,{ }^{*} p<0.1$. 
Table 9: Results of the Biprobit regression on Reverse and Pro-defendant

\begin{tabular}{|c|c|c|}
\hline & Reverse & Pro-defendant \\
\hline \multirow[t]{2}{*}{ Reform in CE } & $0.485^{* *}$ & $-0.825^{* * *}$ \\
\hline & $(0.245)$ & $(0.258)$ \\
\hline \multirow[t]{2}{*}{ Reform in CC } & $0.403^{* *}$ & $-0.573^{* * *}$ \\
\hline & $(0.193)$ & $(0.200)$ \\
\hline \multirow[t]{2}{*}{ Def appeal* Reform } & $-0.769^{* * *}$ & 0.279 \\
\hline & $(0.245)$ & $(0.256)$ \\
\hline \multirow[t]{2}{*}{ Defendant appeal } & $-0.276^{*}$ & $-1.194^{* * *}$ \\
\hline & $(0.145)$ & $(0.149)$ \\
\hline \multirow[t]{2}{*}{ Compliance } & 0.132 & $0.791^{* * *}$ \\
\hline & $(0.139)$ & $(0.149)$ \\
\hline \multirow[t]{2}{*}{ Compensation } & 0.528 & 0.488 \\
\hline & $(0.337)$ & $(0.357)$ \\
\hline \multirow[t]{2}{*}{ Proof } & $0.609^{*}$ & -0.049 \\
\hline & $(0.328)$ & $(0.357)$ \\
\hline \multirow[t]{2}{*}{ Causality } & -0.047 & -0.042 \\
\hline & $(0.183)$ & $(0.186)$ \\
\hline \multirow[t]{2}{*}{ Uncertainty } & -0.219 & 0.418 \\
\hline & $(0.340)$ & $(0.360)$ \\
\hline \multirow[t]{2}{*}{ Procedure } & 0.524 & 0.360 \\
\hline & $(0.323)$ & $(0.346)$ \\
\hline \multirow[t]{2}{*}{ Water } & -0.202 & -0.174 \\
\hline & $(0.187)$ & $(198)$ \\
\hline \multirow[t]{2}{*}{ Soil } & -0.205 & $-0.435^{* *}$ \\
\hline & $(0.197)$ & $(0.212)$ \\
\hline \multirow[t]{2}{*}{ Air } & $-0.528^{* *}$ & $-0.617^{* * *}$ \\
\hline & $(0.225)$ & $(0.238)$ \\
\hline \multirow[t]{2}{*}{ Sea } & -0.101 & -0.161 \\
\hline & $(0.343)$ & $(0.361)$ \\
\hline \multirow[t]{2}{*}{ Noise } & $-0.442^{* *}$ & -0.234 \\
\hline & $(0.206)$ & $(0.211)$ \\
\hline \multirow[t]{2}{*}{ Constant } & $-0.739 * *$ & -0.001 \\
\hline & $(0.341)$ & $(0.357)$ \\
\hline \multirow[t]{2}{*}{ Athrho } & \multirow{2}{*}{\multicolumn{2}{|c|}{$\begin{array}{l}0.227^{* * *} \\
(0.071)\end{array}$}} \\
\hline & & \\
\hline \multicolumn{2}{|l|}{ Observations } & 614 \\
\hline \multicolumn{2}{|l|}{ Log-likelihood } & -615.46 \\
\hline \multicolumn{2}{|l|}{ Wald $\chi^{2}$} & 208.89 \\
\hline \multirow[t]{2}{*}{ Rho } & & 0.230 \\
\hline & & $(0.068)$ \\
\hline
\end{tabular}




\section{Appendix A.}

Table 10 presents the results of a regression in which two interaction variables have been added (Column 3): a variable representing cases determined in the Conseil d'État (supreme administrative tribunal, CE) after the 1987 reform and a variable representing cases determined in the Cour de Cassation (supreme civil court) after the 2001 reform.

Comparing the results of this regression with those of the regression without these interaction variables (Column 2), we observe that the variable Conseil d'État loses significance when taking reforms into account. This confirms the analysis conducted with separate regressions (Table 8). The regression without interaction variables suggests a pro-plaintiff bias in the Conseil d'État. This effect is indeed related to an earlier introduction of the reform in this court w.r.t. the Cour de Cassation. This effect is linked to a selection bias by courts, which remains hidden when one ignores the reforms allowing the supreme courts to have control over their dockets.

Moreover, when comparing the coefficients of the two interaction variables using a Wald test, we see that these two variables have a similar effect. Indeed, under the null hypothesis of equal coefficients, we obtain a $\chi^{2}$ value of 0.66 with a $p$-value of 0.4158 . We thus accept the assumption that the reform has a pro-plaintiff effect of the same magnitude in the two courts. 
Table 10: Probit regression with and without interaction variables

\begin{tabular}{|c|c|c|}
\hline & $\begin{array}{l}\text { Without interaction variables } \\
\text { Selection bias not taken into account }\end{array}$ & $\begin{array}{l}\text { With interaction variables } \\
\text { Selection bias taken into account }\end{array}$ \\
\hline Conseil d'État (CE) & $\begin{array}{l}-0.274^{*} \\
(0.147)\end{array}$ & $\begin{array}{c}0.129 \\
(0.201)\end{array}$ \\
\hline CE after Reform only & - & $\begin{array}{c}-0.547^{* *} \\
(0.273)\end{array}$ \\
\hline CC after Reform only & - & $\begin{array}{l}-0.455^{* * *} \\
(0.158)\end{array}$ \\
\hline Defendant appeal & $\begin{array}{l}-1.073^{* * *} \\
(0.121)\end{array}$ & $\begin{array}{l}-1.081^{* * *} \\
(0.123)\end{array}$ \\
\hline Compliance & $\begin{array}{l}0.683^{* * *} \\
(0.145)\end{array}$ & $\begin{array}{c}0.768^{* * *} \\
(0.149)\end{array}$ \\
\hline Compensation & $\begin{array}{l}0.580^{*} \\
(0.319)\end{array}$ & $\begin{array}{c}0.533 \\
(0.355)\end{array}$ \\
\hline Proof & $\begin{array}{c}0.036 \\
(0.352)\end{array}$ & $\begin{array}{l}0.003^{* * *} \\
(0.354)\end{array}$ \\
\hline Causality & $\begin{array}{c}-0.00153 \\
(0.183)\end{array}$ & $\begin{array}{l}-0.035 \\
(0.187)\end{array}$ \\
\hline Uncertainty & $\begin{array}{l}0.487 \\
(0.357)\end{array}$ & $\begin{array}{c}0.432 \\
(0.358)\end{array}$ \\
\hline Procedure & $\begin{array}{c}0.454 \\
(0.343)\end{array}$ & $\begin{array}{c}0.401 \\
(0.343)\end{array}$ \\
\hline Water & $\begin{array}{l}-0.090 \\
(0.200)\end{array}$ & $\begin{array}{l}-0.172 \\
(0.197)\end{array}$ \\
\hline Soil & $\begin{array}{l}-0.442^{* *} \\
(0.213)\end{array}$ & $\begin{array}{l}-0.427^{* *} \\
(0.212)\end{array}$ \\
\hline Air & $\begin{array}{c}-0.636^{* * *} \\
(0.230)\end{array}$ & $\begin{array}{c}-0.643^{* * *} \\
(0.239)\end{array}$ \\
\hline Sea & $\begin{array}{l}-0.362 \\
(0.390)\end{array}$ & $\begin{array}{l}-0.166 \\
(0.367)\end{array}$ \\
\hline Noise & $\begin{array}{l}-0.134 \\
(0.210)\end{array}$ & $\begin{array}{l}-0.235 \\
(0.211)\end{array}$ \\
\hline Constant & $\begin{array}{l}-0.212 \\
(0.351)\end{array}$ & $\begin{array}{l}-0.032 \\
(0.354)\end{array}$ \\
\hline Observations & 614 & 614 \\
\hline LR test & 195.243 & 207.365 \\
\hline Nagelkerke $R^{2}$ & 0.395 & 0.394 \\
\hline Cox Snell $R^{2}$ & 0.272 & 0.287 \\
\hline C-stat (\%) & 76.71 & 76.87 \\
\hline
\end{tabular}

Note. Standard errors in parentheses, ${ }^{* * *} p<0.01,{ }^{* *} p<0.05,{ }^{* *} p<0.1$. 
Appendix B.

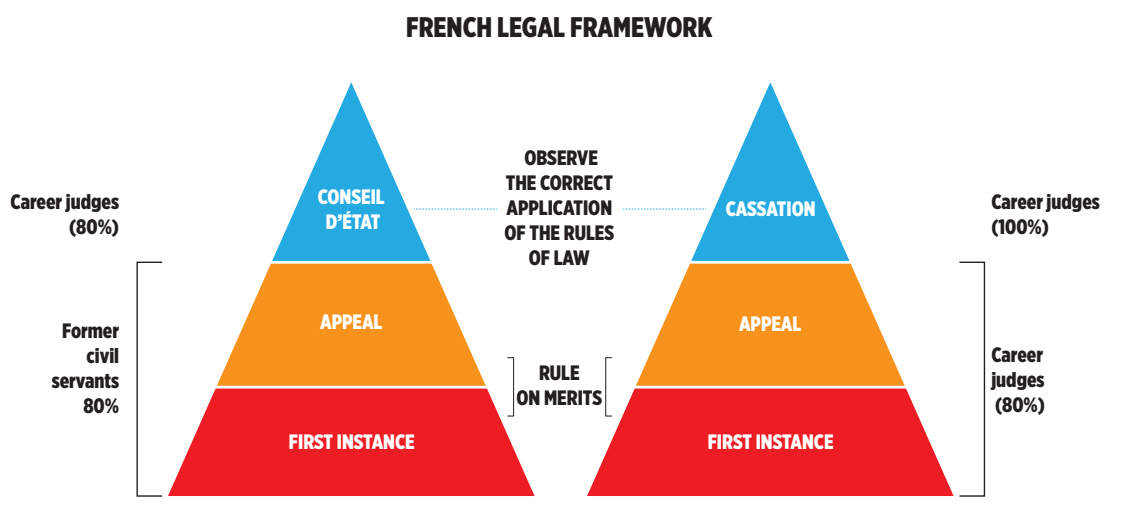

Figure 2: French legal framework 